\title{
Comparative Performance of Five Genotypes of Tomato to Salt Stress
}

\author{
Effat A. Badr ${ }^{1}$, Sanaa A. Riad ${ }^{2}$, Horeya M. Hassan ${ }^{3}$, Ramzy M. Hedia ${ }^{4}$, Yehia A. Moutafa ${ }^{5}$ and \\ Manal A. Zakarya ${ }^{6}$
}

\begin{abstract}
Proline content, chlorophyll pigment and potassium/sodium ratio $\left(\mathrm{Na}^{+} / \mathrm{K}^{+}\right)$of five different genotypes, Edkawy, Castle Rock and Budai Torpe and their hybrids EXC and EXB were significantly increased in proline content and $\mathrm{Na}^{+} / \mathrm{K}^{+}$, and significantly lowered in chlorophyll content by the rise of salinization levels 1.2, 2 , $5,10,15 \mathrm{dS} / \mathrm{m}$. The two hybrids gave a higher response to salinity; this is observed in the increase in $\mathrm{Na}$ and proline in the same time $K$ concentration decreased. Edkawy showed mid values between the other parents and the hybrids.
\end{abstract}

Key words: Lycopersicon esculentum - salinity-proline -chlorophyll

\section{INTRODUCTION}

Salinity is one of the most abiotic stresses that reason for reduction in growth, development and productivity of plants of the world in arid and semi-arid regions, where salts in the soil is high. 45 million hectares of irrigated land are salt-affected throughout the world (Shrivastava and Kumar, 2015).

In developing countries, one of the solutions of the problem of over population densities is to increase productivity of cultivated land. In Egypt, soils suffer from extreme climatic factors such as high temperature and drought as well these conditions caused accumulation of dissolved salts in soils result of the insufficient leaching of ions. Salts accumulation in upper soil layers may also occur due to an unsuitable irrigation management. Plants subjected to excess salt suffer from osmotic regulation, ion imbalance, and oxidative stress, which affect plant metabolism and growth (Mohamed, 2016; Elkhatib et al., 2017).

Tomato, which is an important crop in the world and adapted to various climates, is also undergoing from salinised soils. The cultivated tomato (Lycopersicon esculentum Mill.) is one of the family Solanaceae and is distributed annual vegetable crop. Tomato is also an important crop for breeding programs, because the crosses between wild and cultivated tomato plants are simple and its wild relatives provide a rich germplasm pool. F1 hybrids are one of the targets to meet the demand. F1 hybrids in tomato offer several advantages such as earliness, higher productivity, improved quality and resistance to biotic and abiotic stresses. Like most crop plants tomato is sensitive to moderate levels of salinity. The yield of tomato is affect by salinity; all tomato developmental stages show sensitivity to salt stress (Jones et al., 1986; Maas, 1986; Bolarin et al., 1993; Saad et al., 2018).

Proline is an amino acid present in plants normally. Under environmental stresses, proline is synthesized in large quantities (Ozturk and Demir, 2002; Hsu et al., 2003; Kavi Kishore et al., 2005).

Chlorophyll has the major role in photosynthesis process and chlorophyll content is positively correlated with the rate of photosynthesis (Anjum et al. 2011). Water deficiency and inability of water transport to leaves leads to photosynthesis declines (Loredana et al. 2011). Chlorophyll content decreases in salt susceptible plants such as tomato (Sudhir and Murthy, 2004), under salinity, chlorophyll pigments decreases subsequently photosynthesis rate reduced, as a result the yield negatively affected.

$\mathrm{Na}^{+}$has not an essential role for plants. $\mathrm{Na}^{+}$toxicity occurred because $\mathrm{Na}^{+}$replaced $\mathrm{K}^{+}$roles in tissues in plants under salinity conditions [Blumwald, 2000]. High $\mathrm{Na}^{+}$in the cytoplasmic matrix caused $\mathrm{K}+$ deficiency; damage various enzymatic processes and imposing a vital burden on the cell because of the need to synthesize organic solute required to export of $\mathrm{Na}^{+}$for osmotic adjustment (Munns and Tester, 2008). $\mathrm{K}^{+}$activate the work of the most enzymes in the cell which $\mathrm{Na}^{+}$cannot achieve it. (Tester and Davenport, 2003).

Keeping in view all these points, the present study was undertaken to examine the effects of salt stress on the physiological performance of three tomato cultivars and their two hybrids, mainly $\mathrm{Na}^{+} / \mathrm{K}^{+}$ratio, proline content and chlorophyll content.

\section{MATERIALS AND METHODS}

This study carried out at Sabaheya Station of the Agricultural Research Center, Alexandria, Egypt.

\section{Hybridization Experiment}

Salt tolerant cultivar Edkawy was crossed with salt sensitive cultivar Castle rock and Budai torpe cultivar,

\footnotetext{
${ }^{1.2}$ Genetics Dept., faculty of Agriculture, Alexandria University, Alexandria, Egypt.

${ }^{3,6}$ Sabhia Research Station, Agricultural Researcher Center, Giza, Egypt.

${ }^{4}$ Department of Soil and Water Sciences, faculty of Agriculture,

Alexandria University, Alexandria, Egypt.

Received September 01, 2018, Accepted September 20, 2018
} 
their hybrids were Edkawy x Castle rock (E X C) and Edkawy x Budai torpe (E X B) F1 hybrids.

\section{Salt application}

The two hybrids and their three parents were used in this experiment. Seeds of the five genotypes were planted in peat moss trays. Four weeks old seedlings were transplanted into pots $(25 \mathrm{~cm})$ that contain peat and sand mixture (1:1) and one-half strength Hoagland was used for irrigation. Salinity treatments started seven days after transplanting by irrigated plants with half strength Hoagland solution supplemented by $\mathrm{NaCl}$ in four salinity levels $2,5,10,15 \mathrm{dS} / \mathrm{m}$ beside control $1.2 \mathrm{dS} / \mathrm{m}$. split plot design was used to achieve this experiment with three replicates. Plants salt tolerance was evaluated after 21 days of salt treatment.

\section{$\mathrm{K}^{+}$and $\mathrm{Na}^{+}$determination}

Leaves and roots of plants were dried and $0.1 \mathrm{~g}$ of each sample was digested with $\mathrm{H}_{2} \mathrm{SO}_{4}$ and $\mathrm{H}_{2} \mathrm{O}_{2}$ (Evenhuis and de Waard, 1980). Quantification of $\mathrm{Na}$ and $\mathrm{K}$ ions were done by flame photometer.

\section{Proline content}

For free proline determination, $0.5 \mathrm{~g}$ of each replicate was homogenized with $10 \mathrm{ml}$ sulfosalicylic acid $3 \%$. The homogenate was filtered through Watman No. 1 filter paper. Two $\mathrm{ml}$ of the filtrate were left to react with $2 \mathrm{ml}$ acid ninhydrine and $2 \mathrm{ml}$ glacial acetic acid in a test tube for one hour at $100^{\circ} \mathrm{C}$. The reaction was terminated in an ice bath. $4 \mathrm{ml}$ toluene was used to extract the previous mixture, vigoursly mix for 15-20 5$20 \mathrm{sec}$. Toluene containing chromophore aspirated from the aqueous phase, warmed to room temperature. At 520 $\mathrm{nm}$, optical density of solution measure using toluene as blank. The determination of proline was done using the standard curve according to Bates et al. (1973). The data of proline was expressed as $\mathrm{mg} / \mathrm{g}$ dry weight of leaf tissues.

\section{Chlorophyll content}

Extracts of plant material were obtained from green leaves $0.1 \mathrm{~g}$ by direct immersion in $\mathrm{N}, \mathrm{N}-$ Dimethylformamide (DMF). Approximate ratio of 1:100 (w/v) for green material was used. Then samples solutions were measured for their absorbance by spectrophotometer, then chlorophyll a, chlorophyll b and total chlorophyll were measured according to Moran, 1982.

\section{Statistical analysis}

Data obtained were subjected to statistical analyses using Co-State Software (2004). Mean separation was done using the revised Least Significantly Difference (LSD) test at 0.05 probability level (Steel and Torrio, 1980).

\section{RESULTS AND DISCUSSION}

All salt-stressed plants showed a reduction on growth over the 3 weeks period of salt treatment. Compared to the control plants, the increase in salinity level of the nutrient solution resulted in a gradual reduction of the growth. Castle Rock plants were died at the two highest concentrations $10,15 \mathrm{dS} / \mathrm{m}$ after three weeks of salt treatment.

\section{Proline content}

The content of free amino acid proline of the leaves of all genotypes of tomato showed significant rise with increased of salinity levels (Figure 1). The highest proline content was found at $15 \mathrm{dS} / \mathrm{m} \mathrm{NaCl}$ in the plants of the hybrid EXC followed by hybrid EXB.

It was noticed that the proline content in the sensitive cultivar, Castle Rock was higher than other genotypes at the first three salinity levels, that's agreed with storey and Wyn Jones (1977) reviewed that the increasing in proline content was not an evidence for tolerance but it is response to salt stress. Another study showed that Castle Rock had higher values of proline accumulation than in Edkawy cultivar (Fahmy et al., 1999).

\section{Chlorophyll content}

Chlorophyll content of plant tissue represented to efficiency of photosynthesis process, any factor effect on this vital process reduce the content of chlorophyll pigment. In this study, with increasing of salinity levels, chlorophyll content was reduced in all genotypes.

All tested genotypes showed that the presence of significant difference in the four salinity levels compared to the control group in chlorophyll a, chlorophyll $\mathrm{b}$ and total chlorophyll. The two hybrids had higher values of total chlorophyll than the three cultivars. Castle rock had smallest value of total chlorophyll at the highest salinity level $15 \mathrm{dS} / \mathrm{m}$, whereas Edkawy and Budai Torpe had moderate values between the previous (Figure 2).

\section{$\mathrm{Na}^{+}$and $\mathrm{K}^{+}$measurements:}

$\mathrm{Na}^{+}$content in the leaves and roots increase with increasing salinity levels in all genotypes. This increase was more in leaves than that in the roots (Sarg et al., 1993).

The highest value of $\mathrm{Na}^{+}$was detected in EXB hybrid at salinity level $15 \mathrm{dS} / \mathrm{m}$ followed by EXC hybrid at $10 \mathrm{dS} / \mathrm{m}$.

Potassium ions decreased with the increasing of salinity levels in all genotypes, this indicate that the potassium uptake was decreased in the presence of sodium chloride, which reflect the competition was occurred between $\mathrm{K}^{+}$and $\mathrm{Na}^{+}$ions in the transport 
system inside plants under salinity stress (Albino et al., 2007).
$\mathrm{Na}^{+} / \mathrm{K}^{+}$ratio was higher in shoots than that in roots. The highest value of $\mathrm{Na}^{+} / \mathrm{K}^{+}$ratio (5.70) was observed in EXB at $15 \mathrm{dS} / \mathrm{m}$ followed by EXC at $10 \mathrm{dS} / \mathrm{m}$ (3.98) (Table 1).

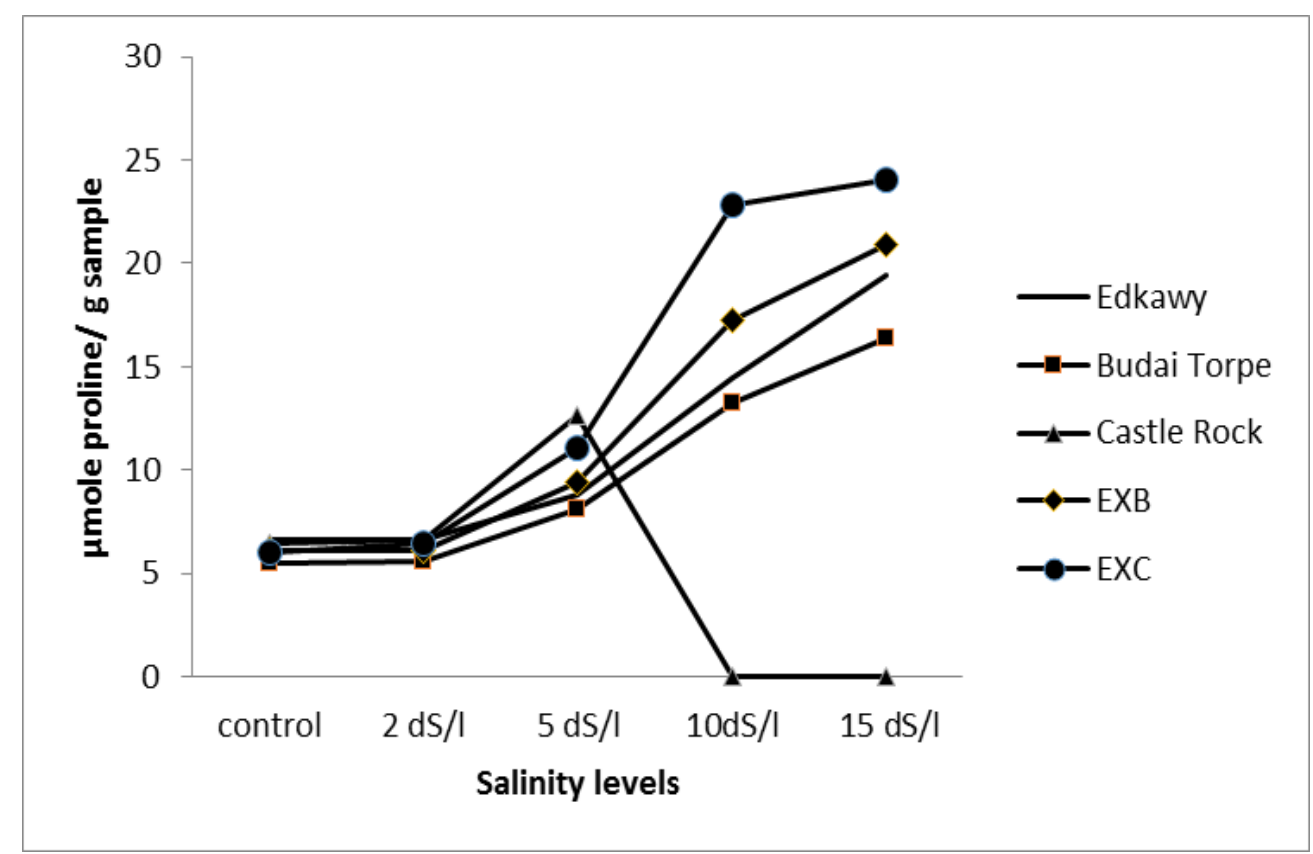

Figure 1. Effect of salinity levels on the average of proline content ( $\mu$ mole/g sample) in the leaves of the five tomato genotypes

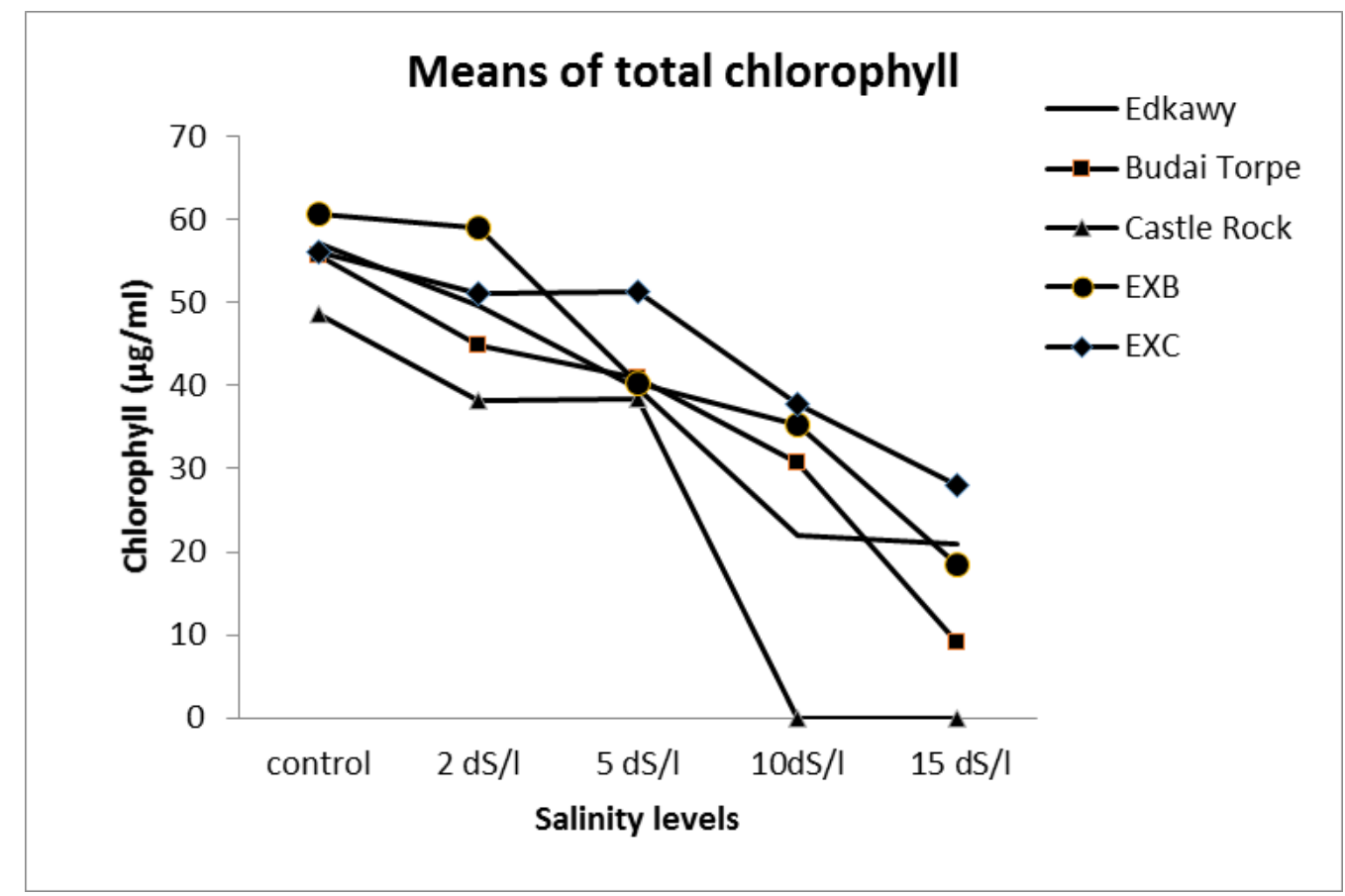

Figure 2. Effect of salinity levels on the average of total chlorophyll $(\mu \mathrm{g} / \mathrm{ml})$ in the leaves of the five tomato genotypes 
Table 1. Na+ (ppm), $\mathrm{K}^{+}(\mathrm{ppm})$ and $\mathrm{Na}^{+} / \mathrm{K}^{+}$of the five tomato genotypes as affected by five salinity levels (T), control, 2, 5, 10, $15 \mathrm{dS} / \mathrm{m}$

\begin{tabular}{|c|c|c|c|c|c|c|c|}
\hline \multirow{2}{*}{ Genotypes } & \multirow{2}{*}{ } & \multicolumn{3}{|c|}{ Shoot } & \multicolumn{3}{|c|}{ Root } \\
\hline & & $\mathbf{N a}^{+}$ & $\mathbf{K}^{+}$ & $\mathrm{Na}^{+} / \mathrm{K}^{+}$ & $\mathbf{N a}^{+}$ & $\mathbf{K}^{+}$ & $\mathrm{Na}^{+} / \mathbf{K}^{+}$ \\
\hline \multirow{5}{*}{ Edkawy } & T1 & $19 \mathrm{ijk}$ & $41.67 \mathrm{a}$ & $0.47 \mathrm{gh}$ & 13ghij & $31 \mathrm{ab}$ & $0.42 \mathrm{ij}$ \\
\hline & $\mathbf{T 2}$ & $10.67 \mathrm{klm}$ & $15.33 \mathrm{gh}$ & $1.35 \mathrm{f}$ & $16 \mathrm{fgh}$ & $28.67 \mathrm{bcd}$ & $0.55 \mathrm{hij}$ \\
\hline & T3 & $11.33 \mathrm{klm}$ & $14 \mathrm{gh}$ & $2.24 \mathrm{de}$ & 17.67efgh & $20.67 \mathrm{def}$ & $0.85 \mathrm{gh}$ \\
\hline & T4 & $42 \mathrm{ef}$ & $11 \mathrm{~h}$ & $3.83 \mathrm{bc}$ & $25.33 \mathrm{~cd}$ & $18.67 \mathrm{efg}$ & $1.35 \mathrm{ef}$ \\
\hline & $\mathbf{T 5}$ & $52.67 \mathrm{~cd}$ & $13 \mathrm{gh}$ & $4.06 \mathrm{bc}$ & $30 \mathrm{bc}$ & $14.67 \mathrm{fgh}$ & $2.04 \mathrm{bc}$ \\
\hline \multirow{5}{*}{ Budai Torpe } & T1 & $9.331 \mathrm{~m}$ & $32.33 b$ & $0.29 \mathrm{gh}$ & $10 \mathrm{ij}$ & $23.67 \mathrm{bcde}$ & $0.44 \mathrm{ij}$ \\
\hline & $\mathbf{T} 2$ & $17 \mathrm{jkl}$ & $28 b c$ & $0.61 \mathrm{gh}$ & $18.33 \mathrm{efg}$ & $31.33 \mathrm{ab}$ & $0.59 \mathrm{hij}$ \\
\hline & T3 & $31.33 \mathrm{gh}$ & $17.33 \mathrm{efgh}$ & $1.97 \mathrm{def}$ & $18.33 \mathrm{efg}$ & $12 \mathrm{gh}$ & $1.56 \mathrm{de}$ \\
\hline & $\mathbf{T 4}$ & 26.67hi & $14.33 \mathrm{gh}$ & $1.86 \mathrm{ef}$ & $22.67 \mathrm{de}$ & $12.33 \mathrm{gh}$ & $1.84 \mathrm{bcd}$ \\
\hline & T5 & $39 f g$ & $10.67 \mathrm{~h}$ & $3.76 \mathrm{c}$ & $25.67 \mathrm{~cd}$ & $11.67 \mathrm{gh}$ & $2.21 \mathrm{~b}$ \\
\hline \multirow{5}{*}{ Castle Rock } & T1 & $8.671 \mathrm{~m}$ & $33.33 b$ & $0.65 \mathrm{~g}$ & $9 j$ & $17.33 \mathrm{efgh}$ & $0.53 \mathrm{hij}$ \\
\hline & $\mathbf{T 2}$ & $32 \mathrm{gh}$ & $23.33 \mathrm{cdef}$ & $0.68 \mathrm{~g}$ & 20def & $14 \mathrm{fgh}$ & $1.43 \mathrm{ef}$ \\
\hline & T3 & $22 \mathrm{ij}$ & $16.33 \mathrm{fgh}$ & $1.37 \mathrm{f}$ & $21.33 \mathrm{def}$ & $18.67 \mathrm{efg}$ & $1.14 \mathrm{fg}$ \\
\hline & $\mathbf{T 4}$ & $0 \mathrm{n}$ & $0 \mathrm{i}$ & $0 \mathrm{~h}$ & 0k & $0 \mathrm{i}$ & 0k \\
\hline & T5 & $0 n$ & $0 \mathrm{i}$ & $0 \mathrm{~h}$ & $0 \mathrm{k}$ & $0 \mathrm{i}$ & $0 \mathrm{k}$ \\
\hline \multirow{5}{*}{$\begin{array}{c}\text { Edkawy } x \\
\text { Budai Torpe }\end{array}$} & T1 & $9.671 \mathrm{~m}$ & $28 \mathrm{bc}$ & $0.34 \mathrm{gh}$ & $10 \mathrm{ij}$ & $37 \mathrm{a}$ & $0.31 \mathrm{jk}$ \\
\hline & $\mathbf{T 2}$ & $11.33 \mathrm{klm}$ & $24.67 \mathrm{cde}$ & $0.46 \mathrm{gh}$ & 15.67fghi & $21 \mathrm{cdef}$ & $0.75 \mathrm{ghi}$ \\
\hline & $\mathbf{T 3}$ & $48 \mathrm{de}$ & 19.33defg & $2.59 \mathrm{~d}$ & $34 \mathrm{ab}$ & $21.33 \mathrm{cdef}$ & $1.60 \mathrm{de}$ \\
\hline & $\mathbf{T 4}$ & $73.33 b$ & $16.67 \mathrm{fgh}$ & $4.39 \mathrm{~b}$ & $36.33 a$ & $21.67 \mathrm{cdef}$ & $1.69 \mathrm{cde}$ \\
\hline & T5 & $85.67 \mathrm{a}$ & $15 \mathrm{gh}$ & $5.70 \mathrm{a}$ & $29.33 b c$ & $10.67 \mathrm{gh}$ & $2.83 \mathrm{a}$ \\
\hline \multirow{5}{*}{$\begin{array}{c}\text { Edkawy x } \\
\text { Castle Rock }\end{array}$} & T1 & $6.67 \mathrm{mn}$ & $29.33 b c$ & $0.26 \mathrm{gh}$ & 12.33hij & $29 \mathrm{abc}$ & $0.45 \mathrm{ij}$ \\
\hline & $\mathbf{T 2}$ & $13.33 \mathrm{klm}$ & $25.33 \mathrm{bcd}$ & $0.53 \mathrm{gh}$ & 13.67ghij & $16.33 \mathrm{efgh}$ & $0.86 \mathrm{gh}$ \\
\hline & T3 & 26.67hi & $13.33 \mathrm{gh}$ & $2.01 \mathrm{de}$ & $22 \mathrm{de}$ & 16.67efgh & $1.32 \mathrm{ef}$ \\
\hline & T4 & $59 \mathrm{c}$ & $15 \mathrm{gh}$ & $3.98 \mathrm{bc}$ & $29.33 b c$ & $9.67 \mathrm{~h}$ & $3.03 \mathrm{a}$ \\
\hline & T5 & $58 \mathrm{c}$ & $15 \mathrm{gh}$ & $3.90 \mathrm{bc}$ & $36.67 \mathrm{a}$ & $11.67 \mathrm{gh}$ & $3.17 \mathrm{a}$ \\
\hline
\end{tabular}

* Means with the same character do not significantly different for each character.

\section{CONCLUSION}

The two hybrids were better than their parents in salinity tolerance demonstrated by the parameters studied under the experiment conditions. This is may be due to hybrid vigour which is the hybrid performed better than parents. It is recommended that these two hybrids Edkawy x Budai Torpe and Edkawy x Castle Rock need some studies for another yield characters.

\section{REFERENCES}

Anjum, S. A., X. Xie, L. Wang, M. F. Saleem, C. Man and L. Wang. 2011. Morphological, physiological and biochemical responses of plants to drought stress. Afri. J. Agri. Res. 6:2026-2032.
Apse, M.P., G.S. Aharon, W.A. Snedden and E. Blumwald. 1999. Salt tolerance conferred by overexpression of a vacuolar $\mathrm{Na}+\mathrm{H}+$ antiport in Arabidopsis. Sci. j. 285: 1256-1258.

Bates, L. S. 1973. Rapid determination of free proline for water-stress studies. Plant and Soil. 39: 205-207.

Blumwald, E. 2000. Sodium transport and salt tolerance in plants. Curr. Opin. Plant Biol. 12: 431-434.

Dasgan, H. Y., H. Aktas, K. Abak and I. Cakmak. 2002. Determination of screening techniques to salinity tolerance in tomatoes and investigation of genotype responses. Plant Sci. 163: 695-703. 
Elkhatib, H. A., S. M. Gabr, A. H. Roshdy and M. M. Abd AlHaleem. 2017. The Impacts of Silicon and salicylic acid Amendments on yield and fruit quality of salinity stressed tomato plants. Alex. Sci. Exch. J. 38: 933 - 939.

FAO(2016):http://www.fao.org/faostat/en/\#data/QC/visualize.

Florina, F., V. Giancarla, P. Cerasela and P. Sofia. 2013. The effect of salt stress on chlorophyll content in several Romanian tomato varieties. J. Hortic. Forest Biotech. 17: 363- 367.

Hassan, A. I .A. 2010. Mean performance ,hetrosis and combining abilities of tomato crosses under saline conditions. J. Agric. Chem. Biotech. 1: 81 - 92.

Honghong, Wu. 2018. Plant salt tolerance and $\mathrm{Na}^{+}$sensing and transport.The Crop Journal. 6: 215-225.

Jones, R. A. 1986. High salt tolerance potential in Lycopersicon species during germination. Euphytica. 35: 575-582.

Loredana, F. C., W. Pasqualina, A. Fuggi, G. Pontecorvo and CarilloPetronia. 2011. Plant genes for abiotic stress, In: Abiotic Stress in Plants - Mechanisms and Adaptations, ed. by Arun Kumar Shanker and B. Venkateswarlu, 855857.

Maas, E. V. 1986. Salt tolerance of plants. .Appl. Agric. Res. 1:12-26.

Maggio, A., G. Raimondi, A. Martino and S. De Pascale. 2006. Salt Stress Response in Tomato beyond the Salinity Tolerance Threshold. Environ. and Experim. Bot. 59: 276-282

Mohamed, N. N. 2016. Land Degradation in the Nile Delta. In: Negm, A.M. (Ed.), The Nile Delta, Springer Berlin Heidelberg, Berlin, Heidelberg. 1-30.
Munns, R. and M. Tester. 2008. Mechanisms of salinity tolerance, Annu. Rev. Plant Biol. 59:651-681.

Oztekin, G. B. and Y. Tuzel. 2011. Comparative salinity responses among tomato genotypes and rootstocks. Pak. J. Bot. 43: 2665-2672.

Ozturk, L. and Y. Demir. 2002. In vivo and in vitro protective role of proline. Plant Growth Regulation 38:259-264.

Saad, A. F.,, A. A. Shalaby, and A. M. Mokhtar. 2018. Influence of Deficit Irrigation Using Saline Water on Yield of Tomato under Two Irrigation Systems. Alex. Sci. Exch. J. 39: 35 - 47.

Sarg, S. M. H., R.G. Wyn Jones and F. A. Omar. 1993. Salt tolerance in the Edkawy tomato. Towards the rational use of high salinity tolerant plants. 2:177-184.

Shrivastava, P. and R. Kumar. 2015. Soil salinity: A serious environmental issue and plant growth promoting bacteria as one of the tools for its alleviation. Saudi J. Biol. Sci. 22:123-131.

Singh, J. , E. V. Sastry, and V. Singh. 2012. Effect of salinity on tomato (Lycopersicon esculentum Mill.) during seed germination stage. Physiol. Mol. Biol. Plants. 18:45-50.

Sudhir, P. and S. D. S. Murthy. 2004. Effects of salt stress on basic processes of photosynthesis. Photosynthetica. 42:481-486.

Tester, M. and R. Davenport. 2003. $\mathrm{Na}^{+}$tolerance and $\mathrm{Na}^{+}$ transport in higher plants. Ann. Bot. 91: 503-527.

Zhang, H. X. and E. Blumwald. 2001. Transgenic salt-tolerant tomato plants accumulate salt in foliage but not in fruit. Nat. Biotech. J. 19:765-768.

$$
\begin{aligned}
& \text { الملخص العربي } \\
& \text { الاداء المقارن بين خمسة تراكيب وراثية من الطماطر تحت ظروف الملوحة } \\
& \text { عفت عبد اللطيف بدر ، سناء احمد رياض، حورية محمد حسن، رمزى مرسى هدية، يحيى عبد السميع مصطفى } \\
& \text { ، منال احمد زكريا } \\
& \text { الناتجان اظهرا رد فعل مرتفع للملوحة حيث وجد فى الزيادة } \\
& \text { الملحوظة فى محتوى البرولين والكلورفيل والصوديوم عن } \\
& \text { باقى التراكيب الوراثية. اما الصنف الادكاوى فاعطى قيم } \\
& \text { متوسطة بين الهجن والابوين الاخريين. } \\
& \text { تم قياس كل من محتوى البرولين والكلوروفيل ونسبة } \\
& \text { صوديوم/بوتاسيوم لكل من الاصناف ادكاوى وبوداى تورب و } \\
& \text { كاسل روك وكذلك الهجن الناتجة منها (ادكاوى x بوداى } \\
& \text { تورب) و (ادكاوى x كاسل روك ) ؛ وقد وجد ارتفاع معنوى } \\
& \text { لكل من صفة محتوى البرولين ونسبة صوديوم/بوتاسيوم } \\
& \text { وانخفاض معنوى لصفة محتوى الكلوروفيل وذلك مع ارتفاع }
\end{aligned}
$$

